J. Clin. Chem. Clin. Biochem.

Vol. 20, 1982, pp. 1-8

\title{
Evaluation of a Monitor Guided Nephelometric System
}

By G. Wider

Zentrallabor des Wilhelminenspitals der Stadt Wien

E. Kulnigg, E. Molinari

Immuno Forschungslaboratorien, Wien

H. Hotschek and P. M. Bayer

Zentrallabor des Wilhelminenspitals der Stadt Wien

(Received May 5/August 26, 1981)

Summary: The most common parameters in the specific protein field, namely the immunoglobulins $G, A$ and $M$ were investigated on the recently developed Immuno Video Nephelomèter System (IVNS). This system consists of the nephelometer, a microprocessor controlled program and a monitor screen, where instructions, standard curve and results are displayed.

Scattered light of immuno-complexes is measured at equilibrium after incubation of prediluted antigen-antibody mixtures.

Data were compared with those obtained by radial immunodiffusion (RID), rate nephelometry (Beckman Immunochemistry System-ICS) and immunoturbidimetry (ENI-Gemsaec).

Intrabatch variation on the Immuno Video Nephelometer System was found to be good (CV 2.6-3.7\%) and day to day variation was satisfactory (CV 3.3-8.6\%).

There was also good correlation between the values found on the Immuno Video Nephelometer System and those of the other methods (correlation coefficients of 0:94-0.98).

- Instrumentation advantages, operation procedure and necessity of antigen excess check are discussed in detail.

Bewertung eines Monitor-gesteuerten nephelometrischen Systems

Zusammenfassung: Auf dem neu entwickelten Immuno Video Nephelometer System (IVNS) wurde die quantitative Bestimmung der Immunglobuline G, A und M untersucht. Dieses System besteht aus dem Nephelometer, dem Mikroprozessor gesteuerten Programm und einem Bildschirm zur Veranschaulichung der Arbeitsanleitungen, der Standardkurve und der Resultate. Streulicht von-Immunkomplexen wird am Endpunkt nach Inkubation der vorverdünnten Antigen-Antikörpermischungen gemessen.

Die Resultate wurden mit dẹen der radialen Immundiffusion (RID), "Rate" Nephelometrie (Beckman Immunochemistry System - ICS) und Immunturbidimetrie (ENI-Gemsaec) verglichen.

Die Präzision in der Serie am Immuno Video Nephelometer System war gut (CV 2,6-3,7\%), die Präzision von Tag zu Tag zufriedenstellend (CV 3,3-8,6\%).

Die Korrelationen der am Immuno Video Nephelometer System ermittelten Werte und denen der anderen Methoden waren ebenfalls befriedigend (Korrelationskoeffizienten: 0,94-0,98). Die Vorteile und Arbeitsweise des Instruments werden im Detail ebenso diskutiert wie die Notwendigkeit der Durchfürung eines "antigen excess checks". 


\section{Introduction}

In recent years immunoglobulin quantitation has become increasingly important. Nowadays clinical laboratories are therefore confronted with an increasing number of these determinations and a fast output of precise results is needed. This implies that immunochemical methods for measuring specific proteins have to be mechanized (1). Actually there are two mechanizable procedures for measuring immuno-complexes as a result of antigen-antibody reaction: nephelometry, involving the measurement of scattered light, and turbidimetry, in which transmitted light is measured. Both procedures can be performed using the equilibrium and the kinetic technique.

We evaluated a recently developed nephelometer system, which is based on the measurement of the light scattering produced by antigen-antibody complexes formed by polymer-enhanced immunoprecipitation reactions at the end-point.

We investigated this microprocessor-monitored Immuno Video Nephelometer System "IVNS" and compared the results with thosè obtained by radial immunodiffusion "RID" (2), immunoturbidimetry "IT" $(3,4,5)$ and the rate-nephelometric Immunochemistry System "ICS" (6).

\section{Materials and Methods}

Instrumentation

\section{Immuno Video Nephelometer System (IVNS)}

This system developed by Immuno, Diagnostic Division, Vienna Austria, consists of the nephelometer, a program module and monitor screen. On the front panel of the apparatus a keyboard, a numcric display for the light scatter units and the sample cell compartment are integrated. The light source is a red filtered tungsten light (wavelength $610 \mathrm{~nm}$ ), which is directed through the axis of the cuvet. The light is focused in the sample by the hemispherical bottom of the test tube, which acts as a condenser lens. The scattered light is detected by two photo cells positioned at a $90^{\circ}$ angle to the incident light path (7) (fig. 1). This arrange-

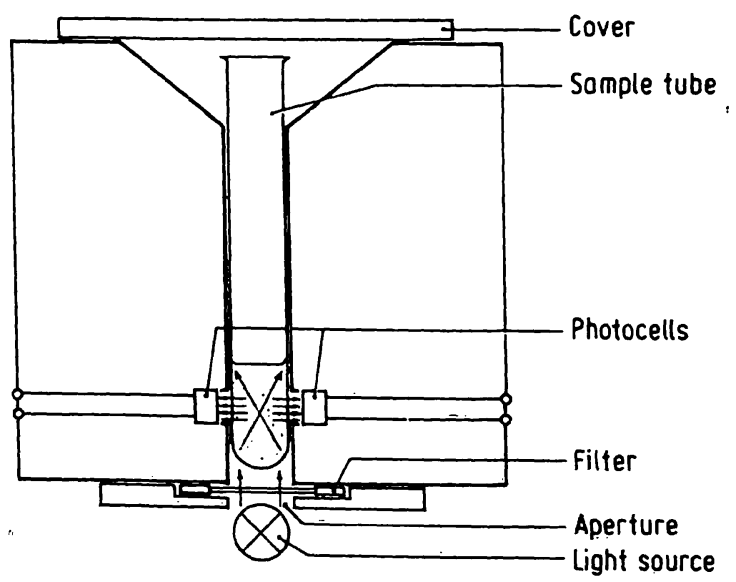

Fig. 1. Sample cell compartment. The scattered light is detected by two photocells positioned in a $90^{\circ}$ angle to the incident light path. Wavelength $610 \mathrm{~nm}$. ment minimizes variations due to differences between test tubes and therefore permits the use of disposable cuvets (8). This was proved by measuring 50 identical samples in different disposable tubes in the mean range (1000 light scattering units). A coefficient of variation of $1.1 \%$ was found.

The electrical current from the photo cells, which depends on the amount of scattered light, is measured, displayed as light scattering units and calculated by the microprocessor. The value are listed on the monitor screen in concentration and international units. The system is completed by a modified pipettor/ dilutor system (SMI, Emeryville, California) for predilution of serum samples and dispensing of blank and reaction reagents, filtering equipment and preparation racks.

\section{Immunochemistry System (ICS)}

This system (Beckman Instruments Inc., Fullerton, California), in contrast to the above mentioned Immuno Video Nephelometer System, is a rate-nephelometer. A tungsten/iodine light source, focusing input optics, a detection optics system at $70^{\circ}$ forward angle, a photomultiplier tube detector and a photodiode for sensing a trigger dye are used. Light in the 400-55.0 nm range is utilized for the scatter measurements.

\section{Radial immunodiffusion (RID)}

For measuring the diameters of the precipitation rings on the immunodiffusion plate a calibrating viewer (Immuno, Diagnostic Division, Vienna, Austria), interfaced with a HP97 calculator (Hewlett-Packard, Corvallis, Oregon 97330) was used. The ring diameters are directly transferred to the calculator where concentration values are computed by linear regression function.

\section{Immunoturbidimetry (IT)}

Immunoturbidimetry analysis were performed on the Gemsaec centrifugal analyzer (Electro-Nucleonics Inc., Caldwell N.J.).

The program used was a DT4 modification, using a calculation for immunochemical determinations $(\mathrm{TC}=7$ ) based on the reference of Blom et al. $(3,9)$.

\section{Reagents}

\section{Antiserum}

Routinely available, nephelometric grade antisera from goats to immunoglobulins $G$ (Lot No.: IGGN101), A (Lot No.: IGAN101) and $M$ (Lot No.: IGMN101) were obtained from Immuno, Diagnostic Division, Vicnna, Austria. These reagents were diluted hundredfold for nephelometry and fiftyfold for turbidimetry with a $40 \mathrm{~g} / \mathrm{l}$ polyethylene glycol 6000 (Merck, Darmstadt; Germany) solution in physiological salinc. For the three immunoglobulins, which are the subject to this investigation, Beckman reagent kits were used on the Beckman Immunochemistry System.

\section{Immunodiffusion plates}

Immunodiffusion was performed on IgG, IgA, and IgM RID endpoint plates (Lot No:: EG01, EAO1 and EMO1, Immuno, Diagnostic Division, Vicnna, Austria).

\section{Reference Standards}

The "Immunoneph Reference Standard human" (Lot. No.: RSN101, Immuno, Diagnostic Division, Vienna, Austria) was used for calibration with the Immuno Video. Nephelometer System and Gemsaec. "ICS Calibrator Serum" (Lot. No., C808257, Beckman Instruments Inc., Fullerton, California), for Beckman Immunochemistry Analyzer. For radial immunodiffusion EP/ON Reference Standards 1-3 (Lot. No.: 01, Immuno, Diagnostic Division, Vienna, Austria) for IgG, A and $M$ were used.

$$
\dot{i}
$$

J. Gin. Chem. Clin. Biochem. / Vol. 20, 1982 / No. 1 


\section{Controls}

"Immunoneph Control Serum human" and EP/ON Control Serum (Lot No.: ICN101 and 01, Immuno, Diagnostic Division, Vienna, Austria) and Precinorm U (Lot No.: 08541, Boehringer, Mannheim, Germany) were analyzed.

\section{Samples}

60 random scrum samples from hospital patients were evaluated for determination of the immunoglobulins $G, A$ and $M$ by the four methods mentioned above. Samples were kept frozen until analysis.

\section{Procedures}

\section{Immuno Video Nephelometer System}

The operator is guided through the analysis stcp by step by instructions appearing on the monitor screen. Antisera were prediluted $1: 101$ with polyethylene glycol buffer solution (10) and after 20 minutes filtered through a $0.22 \mu \mathrm{m}$ pore size membrane filter. With the pipettor/dilutor system three different reagents are simultaneously delivered into separate tubes placed in a sample rack (fig. 2). Into the first tube of a triple row (line C) $2.5 \mathrm{ml}$ of saline solution $(9 \mathrm{~g} / \mathrm{l})$ is pipetted together with $25 \mu \mathrm{l}$ of the previously aspirated sample, control or Reference Standard to prepare a 1:101 dilution. $1 \mathrm{ml}$ of the blank reagent (polyethylene glycol solution) is delivered to a second row (line $B$ ), and $1 \mathrm{ml}$ of the antiserum dilution is delivered to a third line (line $A$ ) of reaction tubes. For IgG $25 \mu \mathrm{l}(\operatorname{IgA} 50 \mu \mathrm{l}, \operatorname{lgM} 100 \mu \mathrm{l})$ of the sample, control or Reference Standard predilutions are sampled into blank and antiserum reaction tubes and incubated for 20 minutes at room temperaturc. Thereafter the endpoint is reached and samples are ready for measurement.

Reaction tubes are inserted into the sample cell compartment of the nephelometer one by onc. Baseline for blank and reagents is set to zero. Based on the light scatter of five standards in a serial dilution, a calibration curve is computed and plotted on the monitor.

Reference curve computation is performed by a non linear least-squares method, using a third order polynomial: $y=a+b_{1} x+b_{2} x^{2}+b_{3} x^{3}$ ( $y=$ concentration values, $x=$ light scattering units).

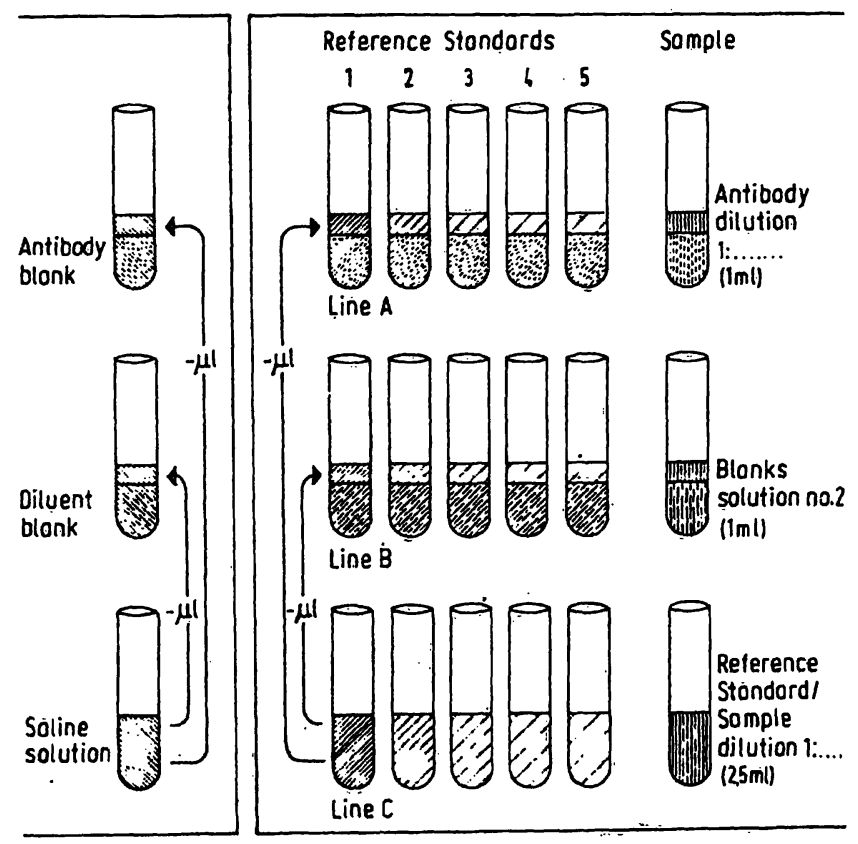

Add eoch....... from Reference Standard/Somple dilution to blanks and ontibody dilution

Fig. 2. Working procedure: Sampling and dilution scheme.
The light scattering values of samples diminished by those of the blanks are displayed on the video screen together with calculated values in concentration and international units. Values are memorized for correction or antigen excess check purposes.

\section{Immunochemistry System}

On the Beckman Immunochemistry System (ICS) proteins were analyzed by rate nephclometry (6). Instrument operating conditions were present by inserting program cards. Reaction tubes filled with polyethylene glycol buffer were introduced into the cell compartement of the instrument, which then calls for a particular calibrator dilution. After addition of a prediluted fluorescein marked antiserum, scatter intensity rises, corresponding to the complex formation in the solution. The analyzer microprocessor converts the peak rate signal into concentration values, which arc shown on the display. For further details see Beckman Immunochemistry Analyzer instruction manual.

\section{Radial immunodiffusion}

Endpoint immunodiffusion plates (RID) for $\operatorname{IgG}, A$ and $M$ were incubated at room temperature. The precipitation ring diameters were measured after 45 hours with the Immuno calibrating viewer and calculated as described above.

\section{Immunoturbidimetry (IT)}

Serum samples and controls were prediluted with isotonic saline $1: 21$ and fillod into the transfer disc on the Rotoloader. The sample volume for IgG was $5 \mu \mathrm{l}$, for IgA $20 \mu \mathrm{l}$ and for IgM $40 \mu \mathrm{l}$ plus a flush volume of $50 \mu \mathrm{l}$ of distilled water. $500 \mu \mathrm{l}$ of the antibody solution, or $500 \mu \mathrm{l}$ polyethylene glycol-saline solution for blank determination are placed into the rotor.

The 16 positions of the transfer disc are loaded in the following arrangement: a water blank in pos. 1, Rcference Standards of decreasing concentrations in position $2-5$, samples and controls in the further positions.

We used the following analyzer settings:

Wavelength: $340 \mathrm{~nm}$. Reaction temp.: $25^{\circ} \mathrm{C}$. Reaction mode: Endpoint read after 240 seconds.

Blank readings were taken in a separatc run 60 seconds after mixing. Blank values were subtracted automatically. For further details see Blom et al. $(3,9)$ and the ENI Gemsaec operating manual.

\section{Time course of antigen-antibody complex formation}

As on the Immuno Video Nephelometer System, the light scatter units are measured at the endpoint, which corresponds to the time for completion of the reaction. For this reason the time course of the complex formation has been investigated on the Immuno Video Nephelometer System and independently on the Beckman Immunochemistry System. The same antibody-antigen ratios as described under procedure for the Immuno Video Nephelometer System were mcasured on both instruments and gave comparable results. Typical curves for the resulting complex formation expressed as scatter increase versus time were recorded (see fig. 5). As shown in this figure, after 20 minutes no significant increase of light scattcr for the three immunoglobulins takes place.

\section{Precipitation curves}

For detection of antigen excess conditions, Reference Standard was serially diluted $1: 50$ to $1: 800$ with physiological saline solution. Certain volumes (IgG: $25 \mu \mathrm{l}, \mathrm{IgA}: 50 \mu \mathrm{l}$, IgM: $100 \mu \mathrm{l}$ ) of the prediluted standards were added to each $1 \mathrm{ml}$ antiserumdilution (antisera/polyethylene glycol buffer $=1: 101$ ). After 20 minutes incubation time the resulting light scatter was 
mensured on the Immuno Video Nephelometer System. Light scattering values were plotted against the corresponding Refercnce Standard concentrations (fig. 4).

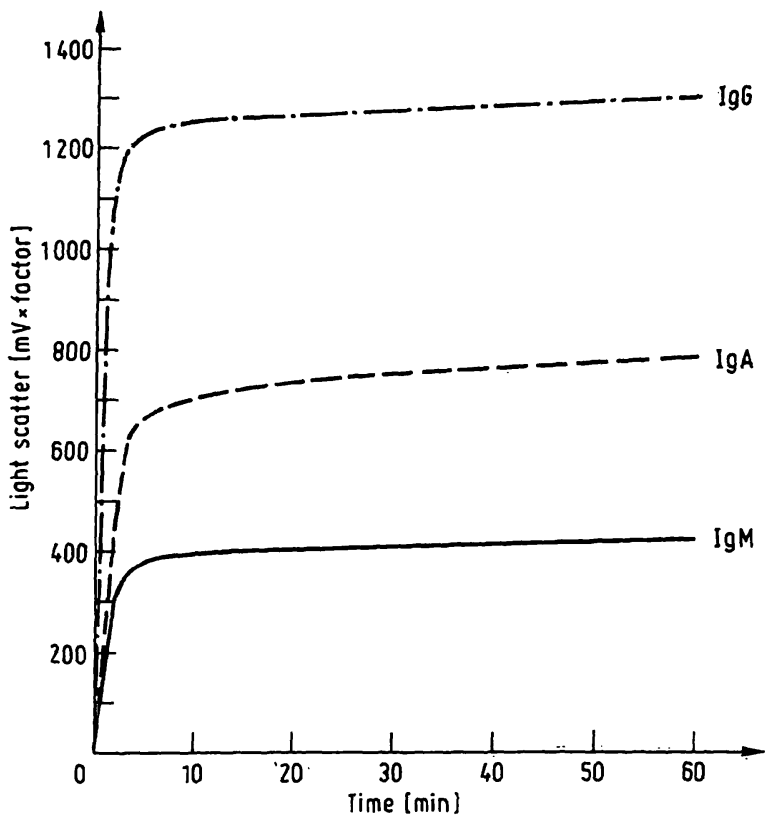

Fig. 3. Time course of antigen-antibody complex formation. After $20 \mathrm{~min}$ no further significant increase in light scattering occurs.

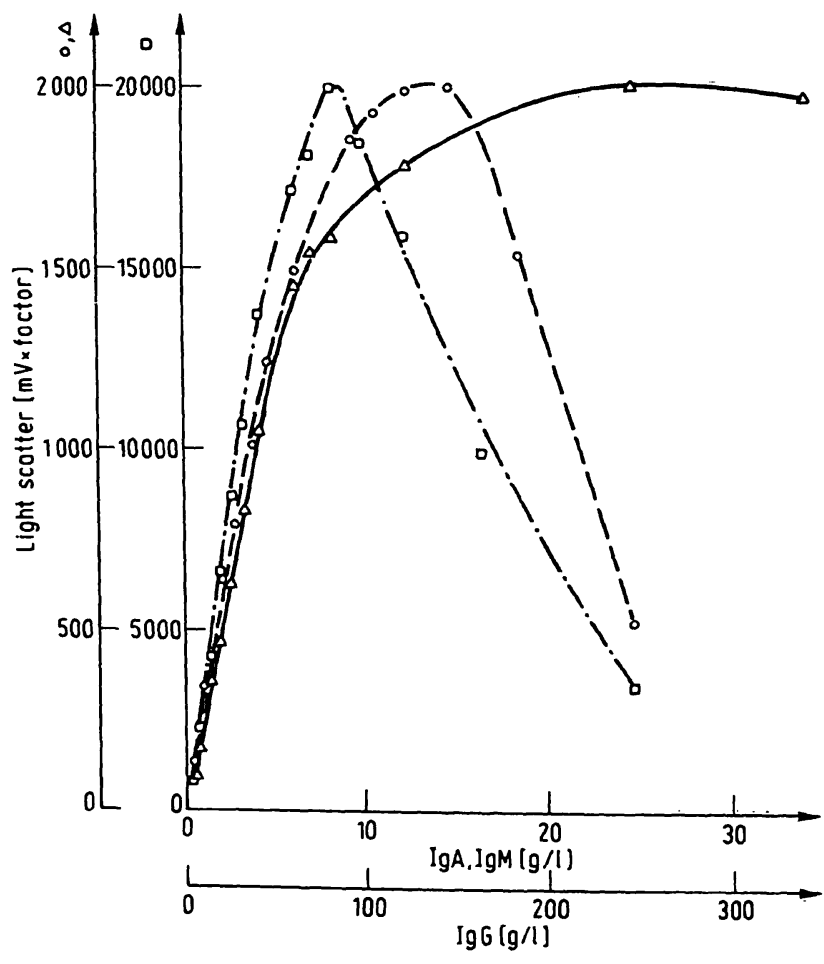

Fig. 4. Precipitation curves. Light scattering values are plotted against corresponding reference standard concentrations. $0-. .0 \operatorname{IgG} ; 0-.-0 \operatorname{IgA} ; \Delta \longrightarrow \Delta \operatorname{IgM}$.

\section{Results}

In nephelometric and turbidimetric assays the formation of antigen antibody complexes is dependent on the ratio of these components. For a constant amount of antibody the complex formation increases adding increasing amounts of antigen up to a maximum, beyond which larger amounts of antigen will result in a decrease of light scatter units because of the formation of soluble complexes (4). Thus, theorétically each light scatter value can be allied with two concentration values. The programmed antigen excess check guide prevents the issue of false low values. Through an antigen excess check it is possible to decide whether the obtained value is in the antibody or antigen excess region. To decide for which immunoglobulin (IgG, IgA, IgM) an antigen excess check has to be performed, a Heidelberger curve for each globulin was recorded and the equivalent point determined (e.g. for IgG this point was found to be $95 \mathrm{~g} / \mathrm{l}$ ). As the concentration value of the highest Reference Standard (that is for IgG $25 \mathrm{~g} / \mathrm{l}$ ) is set to 2000 light scatter units, all values higher than 2000 are out of range of the calibration curve. Above $20 \mathrm{~g} / 1(=2000$ light scatter units on the right hand branch of the Heidelberger curve) values are again below 2000 light scatter units and could represent IgG in antigen excess. All values which are between those limits are recorded as "high". As a known pathological upper limit of IgG is $\sim 140 \mathrm{~g} / \mathrm{l}(15)$, an antigen excess check need not be performed for this serum protein on the Immuno Video Nephelometer System. As for $\operatorname{IgA}, 13 \mathrm{~g} / 1$ was found to be the equivalent point for the antigen-antibody reaction. A possible pathological upper limit $(\sim 100 \mathrm{~g} / \mathrm{l})$ forces an antigen excess check routinely.

The same is valid for IgM: equivalent point $26 \mathrm{~g} / \mathrm{l}$; pathological upper limit $\sim 100$ $\mathrm{g} / \mathrm{l}$. The measuring range at normal serüm dilution according to the programmed working procedure is $3-25$ $\mathrm{g} / 1$ for $\mathrm{IgG}, 0.45-4.40 \mathrm{~g} / \mathrm{l}$ for $\mathrm{IgA}$ and $0.35=2.70 \mathrm{~g} / 1$ for IgM. For determination of higher concentrations than the above mentioned there is no upper limit, because samples can be diluted as necessary. Through further dilution of Reference Standards and amplified span adjustment the measuring range can easily be extended for $\operatorname{lgG}$ downward to $0.0006 \mathrm{~g} / \mathrm{l}$, and for $\mathrm{IgA}$ and $\mathrm{IgM}$ to $0.0005 \mathrm{~g} / \mathrm{l}$.

\section{Prēcision}

For precision control purposes a highter and lower level human serum pool was assayed. Intra assay variation for IgG, IgA and IgM-values obtained by the Immuno. Video Nephelometer System is shown in table 1. The coefficients of variation varied from 2.65 to $3.75 \%$. Inter assay variation (tested on ten successive days) was slightly higher and ranged between 3.29 and $8.61 \%$ (tab. 2). The inter assay variation of the other methods is demonstrated in table 3. 
Tab. 1. Intra assay variation for IgG, IgA and IgM obtained by the Immuno Video Nephelometer System (IVNS).

\begin{tabular}{llrrrrrr}
\hline \multicolumn{3}{c}{ Pool 1 } & \multicolumn{6}{c}{ Pool 2 } \\
\hline $\mathrm{n}$ & & 18 & 18 & 18 & \multicolumn{1}{c}{18} & \multicolumn{1}{c}{18} & 18 \\
$\mathrm{x}$ & $(\mathrm{g} / \mathrm{l})$ & 12.15 & 2.24 & 1.13 & 14.65 & 2.79 & 1.89 \\
$\mathrm{~s}$ & $(\mathrm{~g} / \mathrm{l})$ & 0.33 & 0.08 & 0.04 & 0.38 & 0.07 & 0.06 \\
$\mathrm{CV}$ & $(\%)$ & 2.76 & 3.75 & 3.25 & 2.65 & 2.68 & 3.41 \\
\hline
\end{tabular}

Tab. 2. Inter assay variation for IgG, IgA and IgM obtained by the Immuno Video Nephelometer System (IVNS).

\begin{tabular}{llrrrrrr}
\hline \multicolumn{3}{c}{ Pool 1 } & \multicolumn{6}{c}{ Pool 2 } \\
\hline $\mathrm{n}$ & & 10 & 10 & 10 & 10 & 10 & 10 \\
$\overline{\mathbf{x}}$ & $(\mathrm{g} / \mathrm{l})$ & 12.10 & 2.26 & 1.19 & 15.16 & 2.98 & 1.87 \\
$\mathrm{~s}$ & $(\mathrm{~g} / \mathrm{l})$ & 0.40 & 0.20 & 0.06 & 0.83 & 0.24 & 0.09 \\
$\mathrm{CV}$ & $(\%)$ & 3.29 & 8.61 & 5.48 & 5.46 & 8.05 & 4.75 \\
\hline
\end{tabular}

Tab. 3. Statistical data comparison.

Results obtained by the analysis of two commercial control sera and one serum pool for the immunoglobulins $G, A$ and $M$ with the four methods in this investigation:

IVNS = Immuno Video Nephelometer System

RID = Radial immunodiffusion

ICS = Immunochemistry System

IT = Immunoturbidimetry

\begin{tabular}{|c|c|c|c|c|c|c|c|c|c|c|c|c|}
\hline & \multicolumn{4}{|l|}{ IgG } & \multicolumn{4}{|l|}{ IgA } & \multicolumn{4}{|l|}{ IgM } \\
\hline & IVNS & RID & ICS & IT & IVNS & RID & ICS & IT & IVNS & RID & ICS & IT \\
\hline \multicolumn{13}{|c|}{ Precinorm U } \\
\hline $\begin{array}{l}\frac{\mathrm{n}}{\mathrm{x}}(\mathrm{g} / \mathrm{l}) \\
\mathrm{s}(\mathrm{g} / \mathrm{l}) \\
\mathrm{CV}(\%)\end{array}$ & $\begin{array}{l}10 \\
8.90 \\
0.36 \\
4.1\end{array}$ & $\begin{array}{l}7 \\
8.36 \\
0.97 \\
11.6\end{array}$ & $\begin{array}{l}7 \\
8.07 \\
0.29 \\
3.6\end{array}$ & $\begin{array}{l}10 \\
9.29 \\
0.45 \\
4.9\end{array}$ & $\begin{array}{l}10 \\
1.58 \\
0.13 \\
8.6\end{array}$ & $\begin{array}{c}7 \\
1.64 \\
0.17 \\
10.4\end{array}$ & $\begin{array}{l}7 \\
1.55 \\
0.07 \\
4.4\end{array}$ & $\begin{array}{l}10 \\
1.39 \\
0.07 \\
5.1\end{array}$ & $\begin{array}{l}10 \\
0.78 \\
0.06 \\
7.3\end{array}$ & $\begin{array}{l}7 \\
0.82 \\
0.07 \\
8.4\end{array}$ & $\begin{array}{l}7 \\
0.90 \\
0.03 \\
3.6\end{array}$ & $\begin{array}{l}10 \\
0.50 \\
0.03 \\
5.2\end{array}$ \\
\hline \multicolumn{13}{|c|}{ EP/ON 01} \\
\hline $\begin{array}{l}\frac{\mathrm{n}}{\mathrm{x}}(\mathrm{g} / \mathrm{l}) \\
\mathrm{s}(\mathrm{g} / \mathrm{l}) \\
\mathrm{CV}(\%)\end{array}$ & $\begin{array}{l}10 \\
11.70 \\
0.50 \\
4.3\end{array}$ & $\begin{array}{c}7 \\
12.50 \\
1.17 \\
9.3\end{array}$ & $\begin{array}{c}7 \\
10.75 \\
0.41 \\
3.8\end{array}$ & $\begin{array}{l}10 \\
11.55 \\
0.61 \\
5.3\end{array}$ & $\begin{array}{l}10 \\
1.73 \\
0.14 \\
8.3\end{array}$ & $\begin{array}{l}7 \\
2.10 \\
0.19 \\
9.2\end{array}$ & $\begin{array}{l}7 \\
1.73 \\
0.05 \\
2.7\end{array}$ & $\begin{array}{l}10 \\
1.75 \\
0.08 \\
4.7\end{array}$ & $\begin{array}{l}10 \\
1.34 \\
0.05 \\
4\end{array}$ & $\begin{array}{l}7 \\
1.42 \\
0.14 \\
10.1\end{array}$ & $\begin{array}{l}7 \\
1.37 \\
0.09 \\
6.7\end{array}$ & $\begin{array}{l}10 \\
1.18 \\
0.02 \\
2.1\end{array}$ \\
\hline \multicolumn{13}{|l|}{ Pool } \\
\hline $\begin{array}{l}\frac{n}{x}(g / l) \\
s(g / l) \\
C V(\%)\end{array}$ & $\begin{array}{l}10 \\
15.16 \\
0.83 \\
5.5\end{array}$ & $\begin{array}{l}7 \\
16.43 \\
0.87 \\
5.3\end{array}$ & $\begin{array}{c}7 \\
13.90 \\
0.31 \\
2.2\end{array}$ & $\begin{array}{l}10 \\
15.53 \\
1.61 \\
10.4\end{array}$ & $\begin{array}{l}10 \\
2.98 \\
0.24 \\
8\end{array}$ & $\begin{array}{l}7 \\
3.03 \\
0.35 \\
11.7\end{array}$ & $\begin{array}{l}7 \\
2.79 \\
0.09 \\
3.3\end{array}$ & $\begin{array}{l}10 \\
3.09 \\
0.09 \\
2.8\end{array}$ & $\begin{array}{l}10 \\
1.87 \\
0.09 \\
4.7\end{array}$ & $\begin{array}{l}7 \\
2.31 \\
0.17 \\
7.1\end{array}$ & $\begin{array}{l}7 \\
2.03 \\
0.05 \\
2.3\end{array}$ & $\begin{array}{l}10 \\
1.70 \\
0.07 \\
4.3\end{array}$ \\
\hline
\end{tabular}

\section{Method comparison}

The obtained values of the 60 patients samples analyzed on Immuno Video Nephelometer System were correlated to the other methods and gave satisfactory correlation coefficients between 0.9403 and 0.9864 , but methodical deviations; see figures 5 to 7 . Because of this deviation from the ideal regression line $y=x$ it must be emphasized that reference values have to be elaborated for each method.

\section{Discussion}

We have conducted an investigation of the applicability of different nephelometric devices as well as the precision of those methods. The Immuno Video Nephelometer System is a microprocessor controlled nephelometer for the measurement of the light scattering of immuno- complexes after a steady state of the reaction has been achieved ("endpoint technique").

Conditions for dilution of antiserum, Reference Standard and sample, and the correct mixing ratios and incubation times have been established and are stored as the working procedure in a microprocessor, and can be followed on the screen.

For visual judgement the reference curve is immediately displayed on the monitor after input of the given concentration values and the measured light scatter units.

In "end point" nephelometry resulting light scatter consists of two components: the one due to the complexes plus the other due to background solution $(11,12)$. The necessity of measuring sample blanks which are automatically stored and subtracted from the light scattering value of the reaction mixture was examined. For this purpose each fifty sera of healthy blood donors were measured with and without blanks for the immuno- 

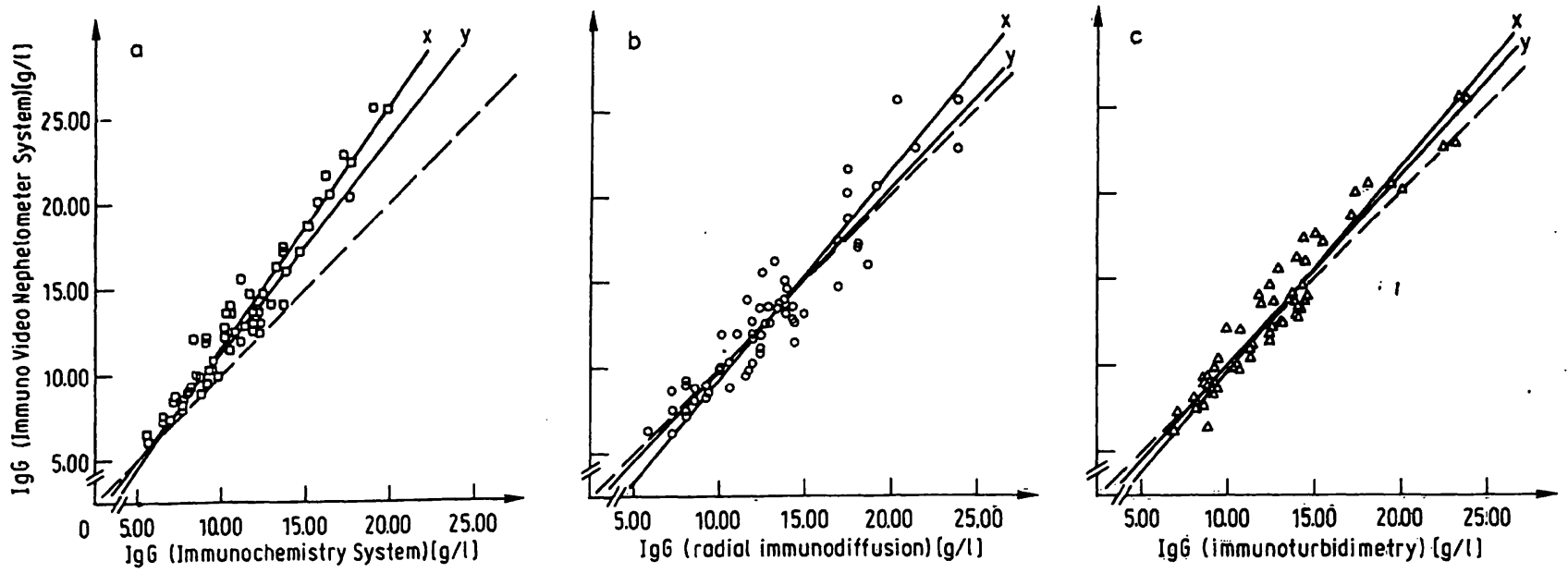

Fig. 5. Correlation betiveen IgG values as measured by Immuno Video Nephelometer System and the corresponding reference method. $\mathrm{n}=$ number of samples; $\mathrm{r}=$ coefficient of correlation; $\mathrm{x}=$ linear regression for reference method; $y=$ linear regression for Immuno Video Nephelometer System; - . . - "ideal" regression line $y=x$.

a) Reference method Beckman Immunochemistry System

$\mathrm{n}=60 ; \mathrm{r}=0.972 ; \mathrm{x}=0.702 \times \mathrm{y}+1.833$

$y=1.348 \times x-1.754$

b) Reference method radial immunodiffusion

$\mathrm{n}=60 ; \mathrm{r}=0.940: \mathrm{x}=0.832 \times \mathrm{y}+2.124$

$y=1.062 \times x-0.727$

c) Reference method immunoturbidimetry $\mathrm{n}=60 ; \mathrm{r}=0.969 ; \mathrm{x}=0.853 \times \mathrm{y}-1.670$ $y=1.100 \times x-1.027$
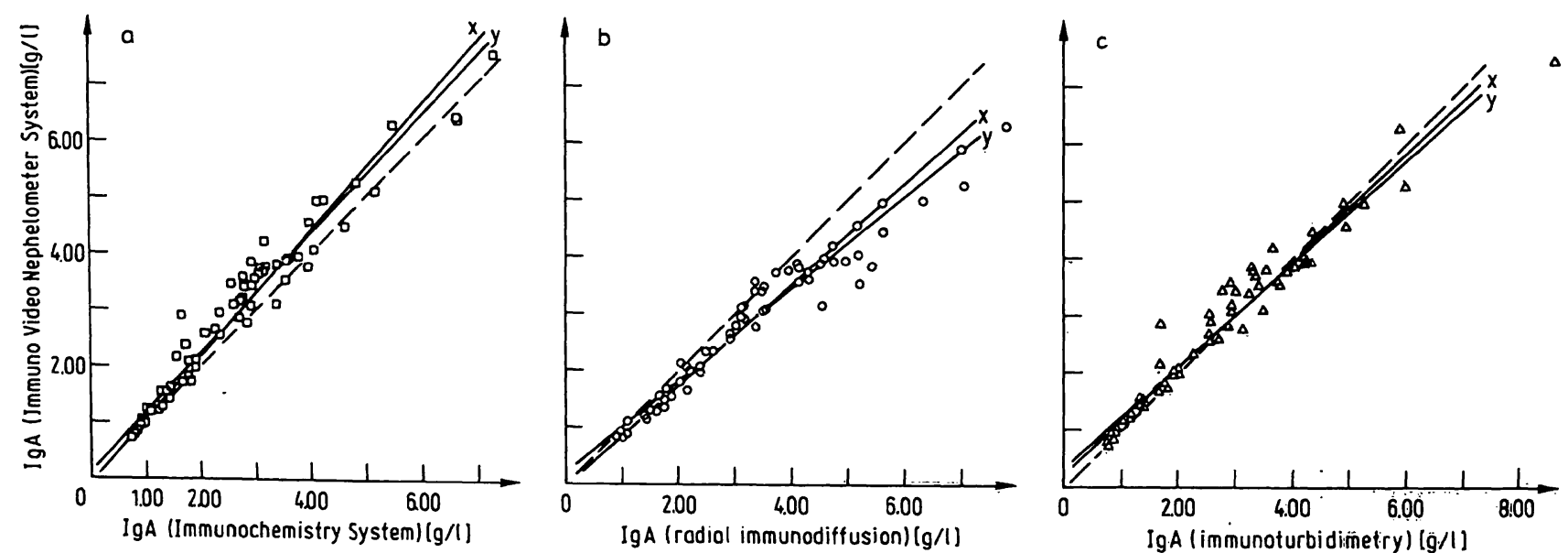

Fig. 6. Correlation between IgA values as measured by Immuno Video Nephelometer System and the corresponding reference method. $n=$ number of samples; $r=$ coefficient of correlation: $x=$ linear regression for reference method; $y=$ linear regression for Immuno Video Nephelometer System; -.... "ideal" regression line $y=x$.

a) Reference method Beckman Immunochemistry System $\mathrm{n}=60 ; \mathrm{r}=0.973 ; \mathrm{x}=0.895 \times \mathrm{y}+0.021$ $y=1.058 \times x+0.133$

b) Reference method radial immunodiffusion $\mathrm{n}=60: \mathrm{r}=0.954 ; \mathrm{x}=1.124 \times \mathrm{y}+0.040$

$$
y=0.809 \times x+0.232
$$

c) Reference method immunoturbidimetry $\mathrm{n}=60 ; \mathrm{r}=0.974 ; \mathrm{x}=1.062 \times \mathrm{y}=0.223$

$y=0.894 \times x+0.347$ 


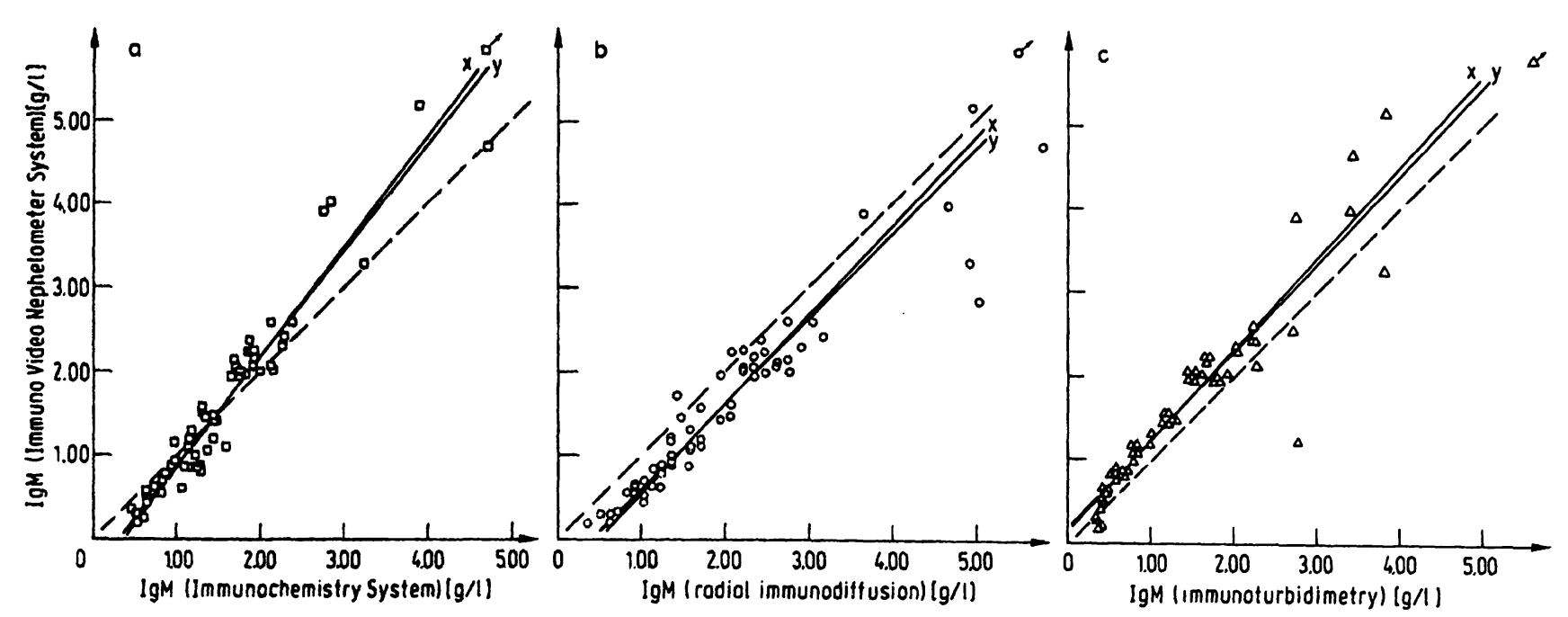

Fig. 7. Correlation between IgM values as measured by Immuno Video Nephelometer System and the corresponding reference method $n=$ number of samples; $r$ = coefficient of correlation; $x=$ linear regression for reference method; $y=$ linear regression for Immuno Video Nephelometer System; .... "ideal" regression line $y=x$.

a) Reference method Beckman Immunochemistry System $\mathrm{n}=60: \mathrm{r}=0.984 ; \mathrm{x}=0.755 \times \mathrm{y}+0.350$ $y=1.282 \times x-0.394$

b) Reference method radial immunodiffusion $n=60 ; r=0.981: x=0.942 \times y+0.477$ $y=1.022 \times x-0.422$

c) Reference method immunoturbidimetry $n=60 ; r=0.985: x=0.916 \times y-0.126$ $y=1.058 \times x+0.187$

globulins $\operatorname{lgG}, \lg A$ and $\operatorname{lgM}$ and the obtained data compared. The values for $\lg G$ and IgA did not differ significantly $(P>0.05)$, while for $\operatorname{lgM}$ there was a significant difference between the values $(P<0.0001)(13)$. The explanation is that for IgM a higher amount of serum dilution is added to the diluted antiserum than for $\lg G$ and IgA-determination. The omission of blanks is timesaving in preparation and measurement. A similar investigation for other serum proteins is currently in progress.

The Immuno Video Nephelometer System gave good correlation and satisfactory precision in comparison to the other methods tested. During a survey variation coefficients from 2.65 to $3.75 \%$ were similar to those found by Zaatari et al. for the Beckman System (16). From day to day precision gave higher coefficients of variation. As a further advantage the trouble resistant optical and electronical design of the nephelometer has to be mentioned. Quickly obtainable results, which are desired nowadays, make this system appropriate for a medium size clinical laboratory with a work load of about 10-50 samples per day and different plasma proteins. For example the three immunoglobulins $G, A$ and $M$ in a series of 50 samples (including antigen excess check for IgA and IgM), 5 standards for the calibration curve and controls can be analyzed in 180 minutes by one person. High antiserum dilution for $\operatorname{IgG}, \operatorname{IgA}$ and IgM ( 100 fold) gives the benefit of low costs.

Radial immunodiffusion is commonly used for immunoglobulin quantitation but requires prolonged incubation time. Although readout of precipitation rings is simplified by a viewer-calculator device, results cannot be obtained within two days using the endpoint method. Rate nephelometry on the Beckman ICS has the advantage of automated aperception of calibrator and antiserum specification as well as single point calibration, which makes determination of single samples economical.

Immunoturbidimetry on the ENI Gemsaec is fast and precise but not as sensitive as nephelometric methods (1).

\section{Acknowledgement}

For skilful technical assistance we thank Miss Eva Buchmann. 


\section{References}

1. Peracino, A.. Marcovina, S. \& Fenili, D. (1978), Ric. Clin. Lab. 8, 113-124.

2. Mancini, G., Carbonara, A. O. \& Heremans, J. F. (1965) Immunochemistry 2, 235-254.

3. Blom, M. \& Horne, N. (1976) Clin. Chem. 22, 657-662.

4. Finley, P. R., Williams, J. \& Byers, J. M. (1976) Clin. Chem. $22,1037-1041$.

5. Wider; G., Hotschek, H., Findeis, I. \& Bayer, P. M. (1979) Lab. Med. 3, 153-156.

6. Sternberg, J. C. (1977) Clin. Chem. 23, 1456-1464.

7. Thorp, J. M., Horsfall, G. B. \& Stone, M. C. (1967) Med. Biol. Eng. 5, 51-56.

8. Kusnetz, J. \& Mansberg, H. P. (1978) In Automated Immunoanalysis Part I (Ritchie R. F., ed.) Marcel Dekker Inc., New York and Basel, pp. 2-43.

9. Blom, M. \& Hjorne, N. (1975) Clin. Chem. 21, 195-198.

10. Hellsing, K. (1978) In Automated Immunoanalysis Part 1

(Ritchie, R. F., ed.) Marcel Dekker Inc., New York and Basel, pp. 67-112.
11. Deaton, C. D., Maxwell, K. W. \& Sïnith, R. S. (1.978) In Automated Immunoanalysis Part 2 (Ritchie, R. F., ed.) Marcel Dekker Inc., New Yọrk and Basel, pp 376-407.

12. Sieber, A. (1977) Laboratoriumspraxis, Laboratoriumsblätter 27, $109=118$.

13. Ostle, B. (1963) Statistics in Research. Iowa State University Press.

14. Heidelberger, M. \& Kendall, F. (1936) J. Exp. Med. 64, $161-162$.

15. Anderson, J. R. \& Sternberg, J. C. (1978) In Automated Immunoanalysis Part 2 (Ritchie, R. F., ed.) Marcel Dekkẹ Inc., New York and Basel, pp. 410-469.

16. Zaatari, G. S., Hamilton, S. R., Jacobs, J. \& Datiles, T. B. (1980) Clin. Chim. Acta 103, 357-366.
Dr. Günter Wider

Zentrallaboratorium des Wilhelminenspitals der Stadt Wien Montleartstraße 37

A-1171 Wien 